\title{
Integration of Islamic Values for Environmental Conservation: An Analysis of School Textbooks
}

\author{
Fatin Nur Marhamah Zabidi ${ }^{1}$, Norshariani Abd Rahman ${ }^{2, * \mathbb{D}}$ and Lilia Halim ${ }^{1}$ \\ 1 Faculty of Education, Universiti Kebangsaan Malaysia, Bangi 43600, Selangor, Malaysia; \\ p95891@siswa.ukm.edu.my (F.N.M.Z.); lilia@ukm.edu.my (L.H.) \\ 2 Institute of Islam Hadhari, Universiti Kebangsaan Malaysia, Bangi 43600, Selangor, Malaysia \\ * Correspondence: norshariani@ukm.edu.my
}

Citation: Zabidi, Fatin Nur Marhamah, Norshariani Abd Rahman, and Lilia Halim. 2021. Integration of Islamic Values for Environmental Conservation: An Analysis of School Textbooks. Religions 12: 509. https:// doi.org/10.3390/rel12070509

Academic Editor: Terry Lovat

Received: 7 May 2021

Accepted: 28 June 2021

Published: 7 July 2021

Publisher's Note: MDPI stays neutral with regard to jurisdictional claims in published maps and institutional affiliations.

Copyright: (c) 2021 by the authors. Licensee MDPI, Basel, Switzerland. This article is an open access article distributed under the terms and conditions of the Creative Commons Attribution (CC BY) license (https:// creativecommons.org/licenses/by/ $4.0 /)$.

\begin{abstract}
Environmental conservation behaviors are associated with one's values toward the environment. This study therefore investigated the values related to conservation behavior from the perspective of a religion. In particular, this study aimed to identify how the Islamic values for environmental conservation were integrated in textbooks. Two textbooks comprising a science textbook and an Islamic education textbook for lower secondary school students (14 years old) in Malaysia were selected in this study. From the findings, it is concluded that both textbooks included the application and integration of Islamic values for environmental conservation based on the contents of the sub-chapters, activities, exercises, notes, and photos. Further, the integration of Islamic values for environmental conservation was mentioned most in the sub-chapter section of these two textbooks. However, findings showed that the science textbook contained numerous integrations of Islamic values for environmental conservation compared to the Islamic education textbook. Thus, the implications of the findings point to the need to establish collaboration between science and Islamic education committees in organizing activities based on science and Islam that are related to environmental education in the teaching and learning sessions.
\end{abstract}

Keywords: Islamic values; environmental conservation; content analysis; textbook; science

\section{Introduction}

Present-day society frequently debates the causes of environmental degradation. There are various causes that have led to the continuing situation such as the apathetic values of some people toward the environment (Schwartz 2012; Abdul Rahman 2016). From the Islamic perspective, humans are responsible for the harmony of nature and its surroundings (Rusdi 2010; Mănoiu et al. 2016). Rusdi (2010) and Mănoiu et al. (2016) stated that people need to be aware of their responsibility in caring for the earth as humans have been appointed as leaders who are entrusted to manage nature and are not the owners of nature. The lack of awareness about this role as the leaders on the earth will lead to these environmental issues becoming a bigger worry as a consequence of the uncaring attitude of people toward the environment and their voracity in exploiting natural resources (Rusdi 2010; Mangunjaya 2010).

Various studies have been conducted to look at environmental problems based on the perspective of Islamic teachings (Haddad 2006; Mangunjaya 2010; Akhter et al. 2010; Rusdi 2010; McKay et al. 2013; Markom and Hassan 2014; Abdul Rahman 2016; Yaacob et al. 2017; Abd Rahman et al. 2019). Abdul Rahman (2017) stated that science and Islamic-based environmental education has been introduced in all primary and secondary schools in Malaysia across the curriculum. However, there is still a lack of awareness on responsible ethical behavior toward the environment among society, and for this reason, this awareness should be inculcated early through education in schools, especially among students.

Based on previous studies, Kamidin and Roslan (2014) described environmental destruction as stemming from internal problems among people. Studies by Abdul-Matin 
(2010) and Rusdi (2010), on the other hand, explained that responsible behavior toward environmental care is being eroded as a result of the lack of appreciation of values related to environmental care based on Islamic teachings. Islamic values for environmental conservation in Islamic teachings as emphasized in the Qur'an include eight (8) key principles: (1) the concept of caliph (the role of humans in the conservation of natural resources); (2) the concept of tauhid (the conviction that "there is no God but Allah"); (3) mizan (balance of nature); (4) fitrah (nature or basic ability created by Allah); (5) qana'ah (accepting wholeheartedly all the blessings of Allah by practicing moderation and being grateful to Allah); (6) mahabbah (love and appreciation of the environment); (7) ihsan (making wise choices, avoiding actions that damage the environment, and taking responsibility for actions); and (8) ta'awun (cooperation in the sense of teaching the family to conserve the environment, reduce the use of natural resources, reduce waste, and engage in environmental conservation efforts and campaigns) (Mangunjaya 2010; Yaacob et al. 2017; Abd Rahman et al. 2020). By increasing awareness of Islamic teachings and human values about environmental conservation, better results will be attained compared to depending solely on efforts of raising public awareness about environmental conservation issues (McKay et al. 2013).

Environmental values have been included in the Malaysian curriculum since 1988. Thus, this means that each subject has a role to play in inculcating environmental values in students. However, from experience and studies (Verma and Dhull 2017), the inculcation of environmental values is often applied in science subjects, for example through topics in biological or physical sciences. Schwartz (2012) highlighted that environmental values are often generic, such as values of responsibility, empathy, respect, caring for nature, and caring for people. However, these values are also discussed in Islamic education. Thus, Islamic education has a role to play not only in the development of people per se but also in the development of people in relation to the environment.

However, there are still some constraints in the integration of values in environmental education at present that should be given attention (Abdul Rahman 2017). Thus, what is needed in helping to reduce this problem is the integration of Islamic values that are related to the environment. Integration of Islamic values related to the environment is warranted and should be implemented through more systematic teaching and learning; one of the methods through which this can be achieved is through the integration of values across the curriculum, for example through textbooks.

In implementing the teaching and learning process, textbooks are the main source of reference used by students and teachers. Textbooks are a global innovation that has had a huge impact on the history of educational development (Love and Pimm 1996). According to Hassan et al. (2019), to date, various kinds of textbooks have been used as a teaching aid in teaching and learning sessions in the Malaysian classroom for teaching of a subject. This shows that textbooks play a huge role in the implementation of the curriculum, particularly for students (Felicia 2008). Thus, the impact of the use of textbooks is comprehensive and wide-ranging, especially for students and teachers.

Since the role played by textbooks in providing guidance and a syllabus for each topic taught to students is huge, this study was therefore conducted with the aim of examining the extent to which textbook contents for the subject of science and Islamic education for lower secondary school students (14 years old) contain the integration of Islamic values for environmental conservation, in particular the extent to which the integration of Islamic values is parallel to the environmental education model—education about, in and for the environment.

\section{Literature Review}

Environmental degradation caused by development is alarming in light of recent natural disasters such as climate change, flash floods, landslides, air pollution, water pollution, land pollution and the extinction of species of flora and fauna. Environmental degradation occurring in a number of Muslim countries, including Malaysia, highlights the importance of emphasizing ethical environmental behavior (Yaacob et al. 2017). Based 
on the research carried out by Abd Rahman et al. (2020), responsible behavior toward environmental care is fading because of the lack of appreciation of Islamic values related to environmental management based on the Qur'an and as-Sunnah. The Qur'an, which is the main source of reference in Islamic teachings, has provided answers to all of the problems in human life (Halim and Akhir 2016). Thus, in this regard, the messages conveyed in the Qur'an, the book of Islamic teachings, should always be referred to and be the guide, including in dealing with environmental issues. In addition, humans should realize and be concerned about their role as caliphs who are responsible for maintaining the well-being and sustainability of the environment.

Palmer (1998) developed a model of environmental education that consists of three elements, namely education about the environment, education in the environment and education for the environment. Education about the environment involves the cognitive aspects of the individual's understanding and knowledge of the environment, while education in the environment is about the aspects of appreciation and emotion that help individuals to become more environmentally sensitive. Education for the environment is about the individual's involvement in the environment and in developing environmental behavior (Palmer 1998; Aarnio-Linnanvuori 2013; Abd Rahman et al. 2019). Based on the environmental education model, one can relate to Islamic education that also teaches about the relationship between God (Allah) and humans (caliphs). As a Muslim, we believe that God created nature and humans to be mutually dependent on one another and to demonstrate the balance between nature and humans. The responsibility of a person who follows the teachings of Islam in carrying out their duties as human beings calls for three main aspects which are the following relationships: with the Creator, with fellow human beings, and between humans and nature (Salleh 2011; Othman 2014; Halim and Akhir 2016; Ruslan 2018; Abd Rahman et al. 2019). This tripartite relationship between the creator, humans and the environment reflects the element of environmental education that is education about, in, and for the environment.

The elements of knowledge, values and behaviors related to environmental conservation should be taken into consideration to improve skills in solving problems related to environmental conservation. According to Elder (2003), the combination of values, knowledge and attitude is capable of developing human skills in solving problems. One of the responsible behaviors toward the environment can be demonstrated through education (Hungerford et al. 2005). Therefore, in the context of education, elements based on the integration of Islamic values for environmental conservation need to be applied in environmental education in order to produce and convey feelings of divinity and appreciation for the greatness of God's creation. Islamic values in school subjects have been addressed in previous studies (Abd Rahman et al. 2020; Abd Rahman et al. 2019; Ahmad @ Shaari 2009). However, it can still be considered quite limited as previous scholars (Haddad 2006; Mangunjaya 2010; Halim and Akhir 2016) have mainly examined the relationship between Qur'anic verses and environmental conservation. Nonetheless, the outcomes from these extant studies form the basis for current research on the implementation of Islamic values for environmental conservation at the school level.

The Ministry of Education Malaysia (MOE) emphasized that the best medium for inculcating environmental education is through educational institutions such as schools (Ministry of Education Malaysia (MOE) 1998). In this regard, environmental education has been implemented across the school curriculum in Malaysia (Ministry of Education Malaysia (MOE) 1998) and integrated together with several subjects in the teaching and learning process as well as through the involvement of environmental clubs available in schools (Abdul Rahman 2017). Starting from 2019, the Ministry of Education Malaysia has striven toward making environmental education one of the subjects to be taught separately (Abdul Rahman 2017). This shows that efforts are being carried out to position the main focus of environmental education in the field of education in order to create a society that is responsible toward the environment. 
Indeed, the effort to integrate environmental education in all subjects across the curriculum has been introduced; however, improvements need to be made in the implementation of environmental education in schools because there still exist constraints in its implementation at the school level. Suffice to say, these constraints in the integration and application of environmental education will continue to occur if no remedial measures are taken. Among the things that need to be examined to overcome these constraints are the readiness of teachers, suitability of teaching materials and the contents of subjects taught by the teachers (Abdul Rahman 2017). Therefore, to integrate environmental education with subject matter, teachers need to have in-depth knowledge of environmental education and be empowered (Ramsaroop and Rooyen 2013). In fact, the need for appropriate tools to teach and integrate environmental education in their teaching can be addressed if teachers are equipped with relevant skills to diversify the learning and the facilitation methods introduced by the government in the Malaysia Education Blueprint 2013-2025 (Ministry of Education Malaysia (MOE) 2013).

\section{Methods}

\subsection{Research Context}

In Malaysia, one entity is responsible for overseeing the publication of textbooks for both primary and secondary schools, i.e., the textbook department of the MOE. Generally, the development of Malaysia's curriculum is handed over to the textbook department of the MOE, where a total of 25 selected textbooks are evaluated based on the content, language, and technical aspects (including the graphics and sensitive issues). The textbooks will then go through an improvement and enrichment process, which is handled by a panel of experts comprising representatives of excellent subject matter teachers, subject matter lecturers, language experts and technical language experts. However, only one book will be selected as the best textbook for each subject and this book will be used in all secondary schools in Malaysia. As a result of the latest revamp of the school curriculum, starting from 2017, all the textbooks published and used for secondary schools in Malaysia are known as the first edition of the Standard Curriculum for Secondary School (KSSM). In short, schools therefore play no direct part in the selection of the publishers who produce textbooks for their secondary level teaching and learning process.

In conducting the research, the first step involved was to identify topics related to environmental education in the textbooks. Based on the examination, it was found that textbooks for Form 2 (lower secondary school) students contained topics related to environmental issues. Therefore, the samples in this research involved the lower secondary school Islamic education textbook and science textbook (Form 2), which are of the latest edition of the Standard Curriculum for Secondary School (KSSM). These KSSM textbooks have been in use with the lower secondary school students in Malaysia since 2017 until the present year. The Form 2 Islamic education textbook selected in this study is specifically written for use in teaching Muslim students only while the Form 2 science textbook is for all students at the lower secondary level (14 years old). Science and Islamic education textbooks were selected because these two disciplines can be expected to be potential subjects for developing the values of environmental education. In order to develop a Malaysian nation where young citizens are nurtured and developed in a holistic and integrated manner, it is aspired that the education system in Malaysia develops individuals who grow to be balanced and harmonious citizens intellectually, spiritually, emotionally and physically (Ministry of Education Malaysia (MOE) 2013). In line with the efforts of the Malaysian government, the educational approach has been changed from one that is academic oriented to one that nurtures the inculcation of universal values. Similar to the National Philosophy of Education (NPE), which states the necessity of universal values for education, the Malaysia Education Blueprint 2013-2025 also aspires to focus on producing citizens who appreciate these values. Therefore, the Islamic values (concepts of caliph, tauhid, mizan, fitrah, qana'ah, mahabbah, ihsan and ta'awun) emphasized in this study are those that correspond to universal values. These universal values are also espoused by 
Schwartz (2012) to be related to the environment. Thus, these values are expected to be integrated across the Malaysian curriculum including in the two disciplines-science and Islamic education-which are taught in school at the lower secondary level. Thus, the analysis of both types of textbooks was based on these values.

\subsection{Data Collection Procedure}

Document analysis is a method for systematically reviewing and evaluating documents. Document analysis requires that data be examined and interpreted in order to elicit meaning, gain understanding, and develop empirical knowledge (Bowen 2009). Data collection through document analysis can provide information relevant to the issue and problem to be studied. Data collection such as source document analysis can augment the evidence to support validation of information obtained from interview results (Ismail 2017). The researchers obtained the Form 2 science and Islamic education textbooks, which are based on the curriculum that have been in use in Malaysian secondary schools since 2017.

In this study, we investigated how content in science and Islamic education textbooks are organized and formulated for the integration of Islamic values for environmental conservation in both textbooks. The contents observed in the textbooks were from the subchapters, activities, exercises, and photos, while the use of Islamic values for environmental conservation was taken as the contextual data for the integration of Islamic values for environmental conservation in both textbooks. Data from the textbooks that fulfilled the criteria of Islamic values integration for environmental conservation were extracted by abstractly reading the textbook contents before they were marked in the review form. The process continued until all the texts and photos related to the integration of Islamic values for environmental conservation had been identified and entered according to the appropriate categories based on each study sample.

\subsection{Data Analysis Procedure}

Document analysis research was chosen to examine the integration of Islamic values for environmental education based on the contents of the sub-chapters, activities, exercises, notes, and photos in the textbooks to explain the items to be described. According to past studies, the content part to be conveyed is obtained by referring to the textual content found in words, meaning, pictures, symbols, ideas, and themes of the printed information (Babbie 2010). Therefore, this qualitative study was entirely performed using the method of document analysis of the textbooks for lower secondary school (textbooks used with 14year-old students). The curriculum used for teaching and learning purposes at secondary schools was identified by utilizing the content analysis review form (as attached in the Supplementary Materials). The content review form was adapted from Liu and Khine (2016). Malaysian textbooks present information as icons and schematics as well as in the form of activities, examples and exercises (Mohamed and Ghazali 2019). Thus, the form was created based on the elements of content that is typical of textbooks in Malaysia. In addition, values could be inculcated through various activities, phrases and representations (Marinkovic and Eric 2014).

In this study, the first edition of the KSSM Form 2 science and Form 2 Islamic education textbooks, compiled and published by Karangkraf Network Sdn. Bhd. in 2017, were analyzed by examining the integration of Islamic values for environmental conservation contained in the contents of both textbooks. The analysis was initially performed by a graduate student. Following this, the outcome of the analysis was then re-examined by two other researchers with backgrounds in science education and environmental education focusing on Islamic values, respectively. A sample of the outcome of each analysis was then compared for agreement on the findings.

\section{Results}

Discussion on the research findings of this study begins by looking at how the integration of the eight Islamic values for environmental conservation is presented and organized 
across the five content sections of the textbooks, namely the chapters, sub-chapters, notes, exercises and photos. The discussion then continues with our observation in relation to the extent to which both the science and Islamic education textbooks promote the integration of Islamic values for environmental conservation.

\subsection{Presentation and Organization of the Contents on the Values}

Reviewing the general presentation and organization of the contents in relation to the values contained in the textbooks, we found that both textbooks promoted the integration of Islamic values for environmental conservation. It can be noted that both samples provide readers with contents that contained the integration of Islamic values for environmental conservation, with nine chapters and six chapters identified for the science and Islamic education textbooks, respectively. In this sample, the science textbook (Khalib et al. 2017) stands out by including content on the values in almost all of its chapters, whereas there is less content about the values in the Islamic education textbook (Wan Abdullah et al. 2017). Nearly all the titles in the science textbook are dominated by environmental terms compared to the Islamic education textbook. The chapter titles in the textbooks that have been found to include the integration of Islamic values for environmental conservation are shown in Table 1.

Table 1. Analysis of chapter titles that contain integration of Islamic values for environmental conservation.

\begin{tabular}{ccc}
\hline No & Science Textbook & Islamic Education Textbook \\
\hline 1 & Chapter 1: Biodiversity & $\begin{array}{c}\text { Chapter 8: Trustworthiness toward Property } \\
\text { and Life }\end{array}$ \\
2 & Chapter 2: Ecosystem & Chapter 11: Strength and Power of God (Allah) \\
3 & Chapter 4: Human Health & Chapter 13: Guidance from Allah \\
4 & Chapter 5: Water and Solution & Chapter 25: Sowing Love, Harvesting Affection \\
5 & Chapter 6: Acid and Alkalis & Chapter 27: Be Polite to Your Neighbors \\
6 & Chapter 7: Electricity and Magnetism & Chapter 28: My Destiny the Mosque \\
7 & Chapter 9: Heat & \\
8 & Chapter 11: Stars and Galaxies in the Universe & \\
9 & Chapter 12: Solar System & 6 \\
\hline Total & 9 & \\
\hline
\end{tabular}

Analyzing entire chapters, the content on the particular values focused in the textbooks was obtained through the inductive mode of analysis, and the analysis also revealed similarities and differences in the integration of Islamic values for environmental conservation across the content sections in the textbooks. Generally, the content sections in the textbooks were found to contain values for environmental conservation that focused on the role of humans as caliphs and values of tauhid, mizan, fitrah, qana'ah, mahabbah, ihsan and t $a^{\prime}$ awun. These values are mapped to the three elements in the environmental education model suggested by Palmer (1998), namely education about, in and for the environment.

\subsection{The Role of Humans as Caliphs (Education about the Environment)}

There are two chapters on the role of humans as caliphs found in the science textbookChapter 2 and 5, titled Ecosystem and Water and Solution, respectively. The role of humans as caliphs in the science textbook was identified in the sub-chapter as well as in the activity sections. The excerpts below, the first three from the science textbook and the fourth from the Islamic education textbook, all represent examples of the role of humans as caliphs:

"Nature is threatened by destruction because of human activities. Humans are responsible for conserving and maintaining the balance of nature." (Sub-chapter 2.4, page 39)

"To carry out a role play to discuss the importance of humans to manage and ensure the sustainability of life." (Activity 2.5, page 40)

"The role of individuals in ensuring water sustainability." (Activity 5.10, page 119) 
"Property and life are blessings from Allah. Everything we have comes from Allah. We must use it to discharge our responsibilities as servants and caliphs of Allah on the face of the earth." (Sub-chapter 1.17.3, page 26)

The excerpts above illustrate the responsibility of humans who play an important role in maintaining environmental balance, which is being jeopardized as a result of the damage caused by human activities. In this regard, students are expected to realize the importance of their role as human beings who are given responsibilities to ensure environmental sustainability through the description in the sub-chapter section of the textbooks. In the activity section, students are exposed to the integration of the values for environmental conservation through the experiment and multimedia literacy activities during the teaching and learning process. Based on previous research, environmental sustainability involves natural resources such as air, soil, forests, and water (Hussin et al. 2015), where it has been proposed that our role in conserving the environment includes taking care of our air, soil, forest and even water. In the Islamic education textbook, it was found that there is a chapter devoted to this value in the content of the sub-chapter in Chapter 8 , Trustworthiness toward Property and Life. However, this chapter stands out only in the paragraphs about the responsibilities of humans as a servant and caliph of Allah and in carrying out their responsibility toward nature.

\subsection{The Qana'ah Value (Education about the Environment)}

One of the Islamic values associated with environmental conservation is the qana'ah, which means treating all of God's creation appreciatively, in a moderate way, as every creature on Earth is created by the Creator, Allah. Examining this value further in the two textbooks, we observed that the terms related to the qana'ah value are found in Chapter 11 of the science textbook and Chapter 8 of the Islamic education textbook. The similarity in the explanation for this value in relation to the integration of Islamic values for environmental conservation is most prominent in the sub-chapter section. In contrast, no qana'ah value was recorded in the activity, exercise and notes sections as well as in the photos of both textbooks. The following excerpt is related to the qana'ah value found in the science textbook:

"The Earth is smaller than a speck of dust in the universe. Can you imagine how vast this universe created by God is? We can never see the end of it. We should be thankful for the beauty of this universe which is a symbol of God's supremacy.". (Sub-chapter 11.1, page 244)

The text in this sub-chapter section begins with a statement, followed by an open question to the student and ends with a value. While the question in the text is used to test students' knowledge, the text above on the whole not only focused on the scientific concept of the universe, it also simultaneously applied the concept of gratitude as a way of believing in the greatness of God as the creator of the universe. Similarly, in the following excerpt taken from the Islamic education textbook in the sub-chapter section, the sign of gratitude toward life and property is described in the text:

"As Muslims, we value wealth by spending it in the way that God (Allah) commands us to as a sign of gratitude.". (Sub-chapter 1.17.6, page 48)

\subsection{The Mahabbah Value (Education in the Environment)}

This section presents the analysis of the integration of the mahabbah value based on the contents in the science and Islamic education textbooks. Mahabbah means love and appreciation of the environment. It is a description that expresses a sense of appreciation toward the environment such as loving and appreciating the balance of nature or the state of equilibrium in nature that Allah has created. Overall, the value of mahabbah found in the Islamic education textbooks is less compared to in the science textbook. Three chapters in the science textbooks were found to contain the integration of the mahabbah value, while only two chapters contained the value in the Islamic education textbook. No mahabbah 
value for environmental conservation was identified in the content section of exercises, notes, and photos. The integration of the mahabbah value was mainly found in the content section of the sub-chapters in the textbooks. The excerpts below are some of the texts taken from the science and Islamic education textbooks that introduce a sense of appreciation for the environment in a way that renders awareness of God's creation. The first three excerpts are from the science textbook, while the last one is from the Islamic education textbook:

"In school, students are instilled with good values through Moral Education to appreciate the balance of nature." (Sub-chapter 2.4, page 40)

"The study of astronomy has raised our awareness of the beauty and vastness of God's creation of the universe." (Sub-chapter 11.1, page 240)

"Human life relies heavily on resources from water and earth, including to get food, manufacturing materials and to generate energy. The increase in human population has caused rapid exploration of the seas and land. Are the Earth's natural resources able to sustain the increasing needs and wants of humans?" (Sub-chapter 12.1, page 263)

"I love flora and fauna. Flora makes my life more beautiful and cheerful. Fauna, on the other hand, maintains the balance of the ecosystem. Flora and fauna also supply food sources that are halal and beneficial for health." (Sub-chapter 6.6.6, page 196)

While the focus on the mahabbah value dominantly occurred in the sub-chapter section, the value can also be found in the Islamic education textbook under the activity section, where the integration of this value for environmental conservation is introduced to students in passages such as the ones below:

"Find information from the internet related to the verses of the Qur'an that commands exploration of nature such as investigating about camels, the skies and earth." (Activity no. 2, page 88)

"In groups, find information on the advantages of loving parents, children, siblings, orphans, disabled people, non-Muslims and animals." (Activity no. 1, page 198)

Based on the activity section above, Chapter 13 and Chapter 25, which were titled Guidance from Allah and Sowing Love, Harvesting Affection, respectively, were identified as containing the value of mahabbah in the Islamic education textbook. Analysis revealed that this section also requires students to practice their skills in searching for information on the particular tasks specified in the activity section either in groups or on their own using the internet. However, the integration of the mahabbah value for the science textbook was only emphasized in the sub-chapter section, while the value was included in two sections in the Islamic education textbook, namely the sub-chapters and activities. This suggests that for the science textbook, the teacher is required to explain the description of the texts; in contrast, for the Islamic education textbook, the mahabbah value is described in the texts and is then mentioned in the activity section so as to increase students' understanding of the integration of Islamic values for environmental conservation.

\subsection{The Ihsan Value (Education for the Environment)}

The value of Ihsan from the perspective of environmental conservation includes avoiding actions that are environmentally damaging, making wise choices in conserving the environment as well as being responsible for environmentally damaging actions. Results showed that all four content sections integrated the ihsan value for environmental conservation except for the notes section. In brief, the science textbook developed its content on the integration of the ihsan value for environmental conservation explicitly in several content sections throughout the textbook. The contents on the ihsan value are most prominently located in the sub-chapter and exercise sections. However, this value was absent from and not even mentioned in the notes section throughout both textbooks. Examples of 
text that contained the integration of the ihsan value that reflects the action of avoiding self-destruction of the environment that were found in the sub-chapter section are as follows:

"Banning the killing or trade of endemic and endangered animals and plants through Wildlife Protection Act 1972." (Sub-chapter 1.1, page 6)

"Protecting the habitat through creating national parks, marine parks, forest reserves and wildlife sanctuaries." (Sub-chapter 1.1, page 6)

"Avoid the use of pesticides that pollute the air and soil by carrying out biological control in agriculture." (Sub-chapter 2.4, page 40)

"Do not spit everywhere." (Sub-chapter 4.1, page 77)

"Enforce laws to ensure industrial waste is treated before being discharged into rivers." (Sub-chapter 5.3, page 118)

"Islam stipulates rules such as the prohibition of taking and using property in vain ways and the prohibition on self-destruction and destruction of others so that human welfare is preserved." (Sub-chapter 1.17.3, page 46)

"Protecting the properties of neighbors and asking for permission if you would like to use it." (Sub-chapter 6.8.4, page 208)

"Do not bring something smelly that it disrupts the comfort of other congregations." (Sub-Chapter 6.9.3, page 212)

The integration of the ihsan value was found in the chapters titled Biodiversity, Ecosystem, Human Health, Water and Solutions, Acids and Alkali, and Heat in the science textbook; and in the chapters titled Being Polite to your Neighbors, Trustworthiness toward Property and Life, and My Destiny the Mosque in the Islamic education textbook. Although the focus on the ihsan value is particularly prominent in the science textbook, as can be seen in the first five excerpts of text taken from the textbook, the value was observed in the Islamic education textbook as well, evidenced in the excerpts of text taken from the textbook above, where the last three were from the Islamic education textbook. Most of the sub-chapters described the prohibition on human beings engaging in environmentally damaging actions in general. The following excerpts of text containing the ihsan value were taken from the activity section in the textbooks:

"Gather information on the topics of river pollution and river cleaning methods.". (Activity 5.10, page 119)

"Design a Green Home where energy used for cooling the house or vice versa can be reduced. You can design or innovate in a local or global context". (Activity 9.5, page 218)

"Reducing noise that may disrupt the peacefulness of the neighborhood.". (Activity, page 210)

The first two excerpts of text above were taken from the science textbook and the last one was from the Islamic education textbook. The first excerpt was on an activity involving the students discussing and finding information about river pollution and the methods to clean rivers so as to avoid environmentally damaging actions. The second excerpt is a project-based learning activity which requires the students to come up with a Green House design to conserve energy use. The third excerpt, however, is a statement that requires students to select items in the checklist that describe themselves in terms of the wise choices that they would make including a few statements related to conservation of the environment. Additionally, apart from the descriptions in the sub-chapters and activities, other examples of the integration of the ihsan value for environmental conservation were found in the exercise section of the science textbook:

"Haze happens more frequently in our country. State the steps to be taken to avoid haze from happening.". (Exercise 2.4, Page 40) 
"City $X$ is well-known as a rat breeding area. Suggest two steps to solve the issue of rat-breeding that can be taken by the authorities and the residents.". (Exercise 2, page 43)

In the exercises, students are asked to propose a few steps or measures to prevent environmentally harmful behavior. It can be seen that in both the excerpts, the exercises are given based on a situation which is first highlighted to the students, followed by a question in the form of a statement asking students to come up with a couple of solutions to overcome the problem in the situation given. Nonetheless, all of the answers to the questions in the exercise can be found in the textbook's previous statement in the subchapter section. Additionally, on page 27 and page 135 of the science textbook, the ihsan value that reflects an effort in being responsible for the environmentally damaging actions is depicted in the photo section. This value can be seen in the photos in Chapter 2 and Chapter 5 as each of these pictures is expected to provide a clear insight for the students on people's responsibilities to save the environment from being contaminated through actions such as creating a planned agricultural system, storing rainwater for daily use, replacing trees and treating alkaline acidic waste before releasing it from factories.

\subsection{The Mizan Value (Education about the Environment)}

Analysis on the integration of the mizan value based on the contents of the textbook revealed that only the science textbook contained the mizan value for environmental conservation. No integration of this value was identified in any of the content sections of the Islamic education textbook. It could be argued that there might be limitations in terms of how the concept of balance and interdependence between other living things in order to achieve the balance of nature can be illustrated in the Islamic education textbook.

All creatures are interdependent on each other. Islam emphasizes the aspect of environmental conservation to create a harmonious, comfortable, and balanced atmosphere which is related to the mizan value. The result of the analysis showed that the mizan value is applied in three chapters of the science textbook, namely in Chapter 2 on the Ecosystem, Chapter 5 on Water and Solution and Chapter 7 on Electricity and Magnetism; each of the chapters emphasizes the interdependence of all living things with each other. The mizan value was found to be commonly developed throughout the sub-chapter, exercise, and photo sections of both textbooks as evidenced in the following excerpts:

"Organism in an ecosystem are interdependent on each other to ensure the survival of the species. These organisms are also interdependent on non-living components in the environment such as water, light, air, and soil. The interdependence that exists between the organisms and their natural surroundings creates a balanced ecosystem. An ecosystem is said to be balanced if the living organisms and non-living components in the environment are in a state of harmony without any external interference. Imagine the state of a forest ecosystem if the trees were cut down. Would this ecosystem still be balanced?" (Sub-chapter 2.3, page 29)

“No life would survive without water.". (Sub-chapter 5.1, page 96)

"Most natural ecosystems are balanced if there is no external interference.". (Photo 2.2, page 29)

"Give two reasons why humans need a balanced ecosystem". (Exercise 2.4, page 40)

"Predict what will happen if the population of fox in that area caught a disease.". (Exercise 2, page 43)

Through the analysis of the sub-chapter section, it was revealed that students are provided with explanations of the importance of adapting to the environment, which also highlights the aspect of interactions between organisms and the environment. However, for the exercise section, the excerpts illustrated above require the students to apply their thinking skills in terms of the importance of a balanced ecosystem and what will happen if there is an imbalance in the ecosystem. In addition, the photo section in the science 
textbook gives an overview of the balance in the natural ecosystems that exist on Earth which are in equilibrium without external disturbances where any external disturbances on the ecosystem would lead to imbalances. Hence, any environmental damage, reduction in resources and occurrences of pollution would lead to imbalances in nature that does not only harm the human life directly, but also threatens our dwellings and the surrounding environment. This shows how the concept of interdependence of one organism on another is developed in the contents of the textbooks.

\subsection{The Fitrah Value (Education about the Environment)}

From the perspective of Islam, nature is the creation of God (Allah), and it belongs to Allah. Muslims believe that everything in the heavens and Earth belongs to Allah including humans, animals, and plants. This realm created by God is fitrah based on the statement in the Qur'an which states that what is in the heavens and Earth is for human consumption. Analysis showed that in the science textbook, a lot more chapters contained integration of this value compared to the Islamic education textbook, with four chapters in the science textbook and one chapter in the Islamic education textbook. Most instances of this value were found mentioned in the sub-chapter section. The excerpts below which contained integration of the fitrah value were predominantly taken from the sub-chapters; the first two were taken from the science textbook while the last one was from the Islamic textbook:

"Water is one of the most valuable natural resources on Earth." (Sub-chapter 5.3, page 113)

"The universe is made up of all that exists around us." (Sub-chapter 11.1, page 240)

"Wealth and life are blessings from Allah. Everything we have is from Allah." (Sub-chapter 1.17.3, page 46)

The excerpts from the science textbook exhibit the general views of the fitrah value in terms of everything in nature belongs to the creator, including humans, animals, and plants. In the Islamic education textbook, the importance of preserving and valuing property and lives is touched upon. This is because wealth and life are blessings from God which are bestowed to all human beings. In the science textbook, there is a section where photos related to the values are presented, and in Chapter 5, there is a photo related to the fitrah value depicting examples of adaptation of life based on the environment. The photo depicts a few areas with tropical, desert and tundra backgrounds. The analysis showed that for photo images, a text explanation is given to the readers in advance in relation to the main content before the photo image is presented. We found that the samples of images are included to assist students in understanding the description given in the text.

\subsection{The Ta'awun Value (Education for the Environment)}

Based on the analysis of the contents in the science textbook, the integration of the ta'awun value was identified in two chapters, namely Chapter 2 on Ecosystems and Chapter 5 on Water and Solution. Analysis of the Islamic education textbook contents revealed that the $t a^{\prime}$ awun value is included in Chapter 25 on Sowing Love, Harvesting Affection. Analysis on the three chapters showed that three content sections of the textbooks contained the value of $t a^{\prime} a w u n$. The three are the sub-chapter, activity and the exercise sections. The value of $t a^{\prime}$ awun identified in Chapter 2 of the science textbook only appeared in the description part of the sub-chapter section as illustrated below:

“The practice of refuse (not to use non-recyclable materials), reduce (reduce the number of materials to use), reuse (reuse the materials), recycle (recycle materials) and repurpose (use the materials for other uses) can reduce waste materials." (Sub-chapter 2.4, page 40)

However, for Chapter 5 (Water and Solution) of the science textbook and Chapter 25 (Sowing Love, Harvest Love) of the Islamic education textbook, the ta'awun value was applied in the activity section. A related observation on how the $t a^{\prime} a w u n$ value is applied 
in the activities and exercises in the textbooks-the first three from the science textbook, the fourth from the Islamic education textbook-is illustrated in the excerpts below:

"Discuss and suggest water conservation steps." (Activity 5.11, page 119)

"Think of an innovative method to conserve water and increase efficiency of water usage." (Activity 5.11, page 119)

"Suggest two steps to save water." (Exercise 2.2, page 27)

"Plan activities with neighbors such as carrying out communal work to clean the housing area." (Activity no. 2, page 210)

Analysis of the activities and exercises provided in both textbooks showed that students are required to discuss the answers and write a report based on a particular given question. It also gives opportunities for students to think creatively and solve problems as not all of the solutions can be found in the previous statement of texts. The ta'awun value includes teaching families to conserve the environment, reduce the use of natural resources, reduce waste, and engage in environmental conservation campaigns. The researchers found that both chapters identified above are related to a variety of nature-based life and resources. In addition, in these two chapters, students are also exposed to recognizing behaviors that can help to reduce waste and save water through the narrative descriptions in the textbooks' sub-chapters, activities, and exercises. As revealed through the analysis carried out on both textbooks, it can be concluded that the ta'awun value has been integrated in the textbooks through the description of sentences in the sub-chapters, activities, and exercises.

\subsection{The Tauhid Value (Education about the Environment)}

Lastly, the integration of the tauhid value for environmental conservation was found in Chapter 11 for both the science and the Islamic education textbooks, titled Stars and Galaxies and the Universe in the former and Strength and Power of God (Allah) in the latter. The integration of this tauhid value was identified in the sub-chapter content section of the science textbook which describes God as the creator of the universe, while in the Islamic education textbook, the value was found in the sub-chapter section in addition to the exercise section as well as the notes section. It could be argued that the integration of the tauhid value was found in additional sections of the Islamic education textbook because of the narrative necessity to describe the strength and power of God as captured in the chapter's title, together with additional examples of Qur'anic verses followed by hadiths. The following excerpts, the first two from the science textbook and the last two from the Islamic education textbook, illustrate how the tauhid value is integrated in the chapters:

"The study of astronomy has raised our awareness of the beauty and vastness of God's creation of the universe." (Sub-chapter 11.1, page 240)

"(1) God rules the whole universe, including the sun, the moon, the stars and the heavens. (2) God has the power to change day and night. (3) God has the power to create the heavens and the earth. (4) Allah sends rain with a certain measure." (Sub-chapter 3.5.3, page 68-70)

"Everything has a creator. This vast universe certainly has a creator. The Creator must be the Almighty and the All-powerful because the universe is vast and complex." (Notes, page 71)

"Describe the natural phenomena and relate them to the nature of Allah's alQawiyy (The Strong)." (Exercise, page 74)

Both the science and Islamic education textbooks' sub-chapters draw the readers' attention to believing in God, the creator of this universe. In Islam, aqidah (faith) is known as the knowledge that reveals the belief of humans in the Creator which is obligatory for every Muslim. Similarly, tauhid can be described as knowledge that debates about the existence of God (Allah), the obligatory attributes of Islam, and the belief in the only 
one God, which is also a part of the aqidah of Muslim people. In short, the connection between the science and the Islamic education textbooks in instilling the value of tauhid for environmental conservation is to reflect on the strength and power of God as the creator, from the smallest of the creations to the biggest in the form of the existence of stars and galaxies in this universe.

\section{Discussion}

The integration of Islamic values for environmental conservation was mentioned most in the sub-chapter section of these two textbooks. Arguably, this is because this section contains texts that require the teacher's explanation on the topic that might have some connection to the Islamic values. Values are something that need to be explained with descriptions such as examples of behaviors or through examples related to students' life. In fact, teachers could also apply the technique of questioning in this section with the students. Nevertheless, the integration of values should be balanced in the contents of the other sections as well such as the activity, exercise, photo, and notes sections as this would make the textbook capable of incorporating the values in an integrated manner for the teachers and students.

Overall, the textbooks for the subjects of science and Islamic education contained integration of Islamic values for environmental conservation. This indicates that students have received education on value integration for environmental education across the curriculum either directly or indirectly through teaching or learning using the textbooks. The findings support $\mathrm{O}^{\prime}$ Riordian (1981) study that claimed there are similarities between environmental education and citizenship education, of which the purpose is to develop commitment and social responsibility that are holistic in terms of the relationship between humans and nature.

The findings indicate that in the context of this study, based on content analysis of the sampled textbooks, there is integration of values for environmental conservation in the textbooks which are used as one of the teaching aids in school to support learning. According to previous researchers, textbooks are teaching aids used by teachers and students in learning sessions (Errington and Bubna-Litic 2015; Yusmium 2015; Juwita et al. 2017; Syahrony et al. 2017). In the teaching and learning process in Malaysia, textbooks are the main source of reference for teachers and students. This is because textbooks are provided for free to all school students in Malaysia based on the implementation of the Textbook Loan Scheme (TBLS), which began in 1975. Through TBLS, the government has worked at the initiative of lending out textbooks for free, initially provided to underprivileged students and later given for free in stages to students of all walks of life regardless of family background.

This study was performed to explore the contents of selected textbooks identified in the study sample. School textbooks are viewed as something that is influential in the education system of Malaysia to the point that they affect students' performance in school (Peters and Abdullah 2017). Therefore, the use of textbooks as a basic reading material for any subject in order to accomplish the teaching and learning process can no longer be denied; indeed, they are still being used today in schools (Hassan et al. 2019). This shows that textbooks have a huge role in the teaching and learning process in the classroom and usage of the textbooks will have a comprehensive and wide-ranging impact on students and teachers.

The prominence given to questions and activities in the form of values in the education system of Malaysia should be given attention. Through the Curriculum Development Centre (CDC) (1988), the aspect of moral value integration began to be given serious attention during the implementation of the previous education system, namely the Integrated Curriculum for Primary School (KBSR) and the Integrated Curriculum for Secondary School (KBSM). This clearly proves that the emphasis on values has been exposed to students starting from the primary school up to the secondary school. The integration of these values across the curriculum also encourages teachers to use the cross-curricular value 
integration approach, so that these values are not only integrated in the subjects of Islamic Education, Moral Education, Civic and Citizenship Education but in all other subjects as well (Hashim 2000; Ministry of Education Malaysia (MOE) 2019).

Integration of values across the curriculum is in line with the goals of the National Education Philosophy (NEP) which focus on holistic human capital development and even coincide with the Malaysia Education Blueprint 2013-2025 that focuses on the aspiration to produce citizens who appreciate values by reintroducing Civic Education at the school level (Ministry of Education Malaysia (MOE) 2013). Civic Education began to be implemented again in an integrated manner in all subjects and curricular activities in school starting from 2019. This is because value education in school is for the purpose of character and personality development among students (Ministry of Education Malaysia (MOE) 2019).

The findings of this study act as one of the alternatives in inculcating Islamic values for positive behavior toward the environment through the contents of science and Islamic education textbooks used in schools. Results of this study show that the contents of the science textbook were identified to contain nine chapters that integrated Islamic values for environmental conservation while the contents of the Islamic education textbook indicated six chapters that integrated Islamic values for environmental conservation.

It was found that integration of Islamic values for environmental conservation in the science textbook was higher compared to the Islamic education textbook. The researchers opined that this is because science education is often associated with the environmental field other than about scientific knowledge that covers facts and concepts and new discoveries through research studies. This is supported by Amirshokoohi (2010) and Weiland and Morrison (2013) who argued that the field of environmental education is often linked to the contents of science education. In fact, according to Gumilar et al. (2020), science education is the only subject where students learn about scientific research on human relationships and interactions with aspects of natural objects.

In the context of science education in Malaysia, science textbooks are a subject content that revolves around the human environment and is also related to the natural environment. Basically, the field of science education at the secondary level refers to an extensive field while for the upper secondary level, the science field is divided into Biology, Chemistry and Physics. At the lower secondary level, it is basic science education.

According to the contents of the 2017 KSSM Science Education Curriculum and Assessment Standard Document (DSKP), the main focus related to environmental education can be identified particularly in Chapter 1 (Biodiversity) and Chapter 2 (Ecosystem). Among the learning outcomes integrated in these two chapters are students being able to identify diversity of organisms created by God and being able to differentiate that each living thing in nature has its own function, that there is interdependence of each living thing on Earth and that humans have a role to play in maintaining the balance of nature.

Based on a previous study carried out abroad by Zandvliet (2001), integration of environmental elements in science education can facilitate understanding of science concepts, scientific enquiry, development of aspects of skills and cognition, and the use of the natural environment as context for exploring real problems. This is also supported by Chopra's (2015) study, where science education and environmental education were found to contribute to one another particularly in science curriculum. A previous study in Indonesia found that by using appreciation that is related to the environment as a source in science learning, performance and achievement in science learning can be enhanced (Brahim 2007). This indicates that science education is so closely related to environmental education that they affect each other in the teaching and learning sessions in school.

In contrast, based on the contents of the Islamic education textbook, integration of Islamic values for environmental conservation was found to be less than that in the science textbook. The field of Islamic education is more directed toward developing students' identity in line with values that are based on Islamic teachings (Mohamad et al. 2008; Ahmad and Aljufri 2019). This is because in general, Islamic education is one of the channels for developing character and shaping the thinking of the society, especially students. 
In addition, the concept of Islamic education is to describe values for each human behavior and norms that follow the teachings of Islam (Ahmad and Aljufri 2019). The ultimate goal is for humans to behave in accordance with the principles of Islam and become a better human being. This is because this all-encompassing Islamic education is education of quality that subsequently contributes to the development of the individual physically, cognitively, psychologically, spiritually, morally, socially and the entire knowledge discipline toward attaining good in this world and prosperity in the hereafter (Mohamad et al. 2008).

The main focus of the contents of the Islamic education textbook is concentrated toward developing and shaping servants and caliphs of Allah who are knowledgeable, pious, perform good deeds, of virtuous character, and have competency based on the mold of the Qur'an and as-Sunnah in totality (Wan Abdullah et al. 2017). However, findings showed the contents of the Islamic education textbook do not contain specific chapters that are based on the concept of environmental education. As a result, the contents of the Islamic education textbook do not have specific topics that teach environmental education. This presents an overview of the role and direction of Islamic education in showcasing its goal of shaping Muslim personalities, which comprises the spiritual, physical, emotional, and intellectual aspects, in a harmonious and balanced manner in line with the goals of the National Education Philosophy (NPE).

Based on the findings of this study, integration of Islamic values for environmental conservation was most often found in the contents of the sub-chapter section of both textbooks. Therefore, the implication is for the textbook division of the Ministry of Education, Malaysia to carry out evaluation and review of the integration of universal values derived from Islamic values for environmental conservation especially in the contents of the notes section and the photo section so as to attract students to read these sections. Additionally, teachers have a role to understand the purpose of education itself, which is to create divine characteristics in human beings among the students for their own good and for the good of society.

\section{Conclusions}

This study attempted to identify the integration of Islamic values for environmental conservation applied in the science and Islamic education textbooks used in secondary schools. Textbook research is indeed an effort that needs to be implemented from time to time, and it needs to be carried out through different perspectives in order to be able to work toward developing a curriculum that is more holistic. The content analysis perspective was used in this study on integration of Islamic values for environmental conservation, and the findings obtained from the analysis indicate the need to refine the textbooks and to discretely carry out improvements in terms of the Islamic elements for environmental conservation because this is considered as a necessity, especially for students of an Islamic science-integrated school background.

Results from this analytical study are expected to provide suggestions for improvements in the textbooks in terms of integration based on values related to environmental conservation from the Islamic perspective in order to fulfill the learning objectives of environmental education in schools. This effort is expected to be one of the alternative approaches in the development of more robust textbook curriculum that lay importance on integration of values to produce students who appreciate their role as human beings who are responsible toward the environment. Therefore, establishing collaboration between the science and the Islamic education committees in terms of organizing activities based on science and Islam that relate to environmental education in the teaching and learning sessions is greatly needed.

Future studies should be directed toward identifying the effectiveness of the inculcation of the integration of values through textbooks. It is hoped that this effort can help in creating awareness on the importance of always showing ethical behavior toward the environment, especially among secondary school students. 


\section{Recommendation and Limitations}

Solving environmental issues is a multidisciplinary endeavor. All disciplines have a role to play. This study suggests that Islamic education should extend its role toward environmental education. In particular, the contents of the textbook could relate more to the values and the context of environmental education.

In addition, it is proposed that the agencies involved in designing the curriculum consider enhancing the contents of science and Islamic education textbooks further by including appreciation of values in each chapter that is geared toward environment-based context. Integration of values should also be greatly emphasized through activities and exercises in the textbooks so that knowledge of the values could be transformed into actions.

This study only investigated the integration of Islamic values in science and Islamic education textbooks for lower secondary school, and the textbooks are only for a particular level of schooling (Form 2 for lower secondary school). It is acknowledged that other textbooks in other subject matters such as Geography or English may have integration of Islamic values and discussion of topics on the environment as well.

Another limitation was that no classroom observation or interview with teachers and students was conducted in relation to how the teaching of values was explicated verbally or transformed into hands-on activities. Furthermore, the effectiveness of the suggested activities for integration of the values into the science or Islamic education content was not assessed.

Supplementary Materials: The supplementary materials are available online at https:/ /www.mdpi. com/article/10.3390/rel12070509/s1.

Author Contributions: Data curation, F.N.M.Z.; Formal analysis, F.N.M.Z. and N.A.R.; Methodology, F.N.M.Z.; Project administration, N.A.R.; Resources, N.A.R.; Supervision, N.A.R. and L.H.; Validation, N.A.R. and L.H.; Writing—original draft, F.N.M.Z.; Writing—review \& editing, N.A.R. and L.H. All authors have read and agreed to the published version of the manuscript.

Funding: This study was funded by research grant GGPM-2018-033, Universiti Kebangsaan Malaysia.

Institutional Review Board Statement: Not applicable.

Informed Consent Statement: Informed consent was obtained from all subjects involved in the study.

Data Availability Statement: The data supporting reported results can be found this link: http: // online.anyflip.com/rzgru/kvda/mobile/index.html (Science textbook) and http://online.anyflip. $\mathrm{com} / \mathrm{dmkhg} / \mathrm{miah} / \mathrm{mobile} /$ index.html (Islamic education textbook).

Conflicts of Interest: The authors declare no conflict of interest.

\section{References}

Aarnio-Linnanvuori, Essi. 2013. Environmental Issues in Finnish School Textbooks on Religious Education and Ethics. NordidacticaJournal of Humanities and Social Science Education 1: 131-57.

Abd Rahman, Norshariani, Fatin Nur Marhamah Zabidi, and Lilia Halim. 2020. Integration of Tauhidic Elements for Environmental Education from the Teachers' Perspectives. Religions 11: 394. [CrossRef]

Abd Rahman, Norshariani, Fatin Nur Marhamah Zabidi, Mohd Yusof Othman, Lilia Halim, Zanaton Iksan, and Wan Nasyrudin Wan Abdullah. 2019. Conceptual framework for integration of tauhidic elements for environmental conservation (TEFEC): A Review. International Journal of Academic Research in Progressive Education and Development 8: 70-83. [CrossRef]

Abdul Rahman, Haliza. 2016. Solving the Environmental Crisis: Why Islam? Seminar Serantau Pengurusan Persekitaran. Available online: https://www.researchgate.net/profile/Haliza_Abdul_Rahman2/publication/309856207_Penyelesaian_Krisis_ Alam_Sekitar_Mengapa_Islam/links/58255a2208ae7ea5be780c4f/Penyelesaian-Krisis-Alam-Sekitar-Mengapa-Islam (accessed on 20 June 2019).

Abdul Rahman, Haliza. 2017. Efforts and challenges in applying environmental education in the school system in Malaysia. Asian Journal of Environment 1: 61-70.

Abdul-Matin, Ibrahim. 2010. GreenDeen. What Islam Teaches about Protecting the Planet. Oakland: Berrett-Koehler Publishers.

Ahmad, Ahmad, and Sakinah Aljufri. 2019. Islamic education shapes the values and character of students. Journal Pendidikan dan Pembelajaran 2: 1-8. 
Ahmad @ Shaari, Mohammad Zohir. 2009. Application of Environmental Education in the Teaching of Geography in Secondary Schools: Knowledge, Attitudes, Effectiveness and Practice of Teachers. Ph.D. thesis, Faculty of Education, Universiti Kebangsaan Malaysia, Bangi, Malaysia.

Akhter, Mumtaz, Tanveer Iqbal, and Musbashra Khalid. 2010. Islamic educational approach to environment protection: A strategic approach for secure and peaceful world. International Journal of Business and Social Science 1: 182-91.

Amirshokoohi, Aidin. 2010. Elementary preservice teachers' environmental literacy and views toward Science, technology, and society (STS) issues. Science Educator 19: 56-63.

Babbie, Earl. 2010. The Practice of Social Research. Boston: Wadsworth Cengage Learning.

Bowen, Glenn. A. 2009. Document Analysis as a Qualitative Research Method. Qualitative Research Journal 9: 27-40. [CrossRef]

Brahim, Theresia K. 2007. Improving Science learning outcomes for grade IV primary school students, through the approach of utilizing natural resources in the environment. Jurnal Pendidikan Penabur 9: 37-49.

Chopra, Shruti. 2015. Integrating environmental and Science education: Issues and possibilities. Educational Quest 6: 111. [CrossRef]

Curriculum Development Centre (CDC). 1988. Virtuous Values in KBSM: A Challenge for Educators. Kuala Lumpur: Kementerian Pendidikan Malaysia.

Elder, James L. 2003. A Field Guide to Environmental Literacy: Making Strategic Investments in Environmental Education. Manchester: Environmental Education Coalition.

Errington, Alison, and David Bubna-Litic. 2015. Management by textbook: The role of textbooks in developing critical thinking. Journal of Management Education 39: 774-800. [CrossRef]

Felicia, Nisa. 2008. Cognitive Analysis in Primary School Mathematics Textbooks in Indonesia and Its Relevance to the 2004 Curriculum: A Content Analysis. Master's thesis, Faculty of Education, Universiti Kebangsaan Malaysia, Bangi, Malaysia.

Gumilar, Rena Prihatna, Sri Wardani, and Lisdiana Lisdiana. 2020. The implementation of guided inquiry learning models on the concept mastery, scientific attitude, and Science process skill. Journal of Primary Education 9: 148-54.

Haddad, Marwan. 2006. An Islamic approach towards environmental education. Canadian Journal of Environmental Education (CJEE) 11: 57-73.

Halim, Imaaduddin Abdul, and Noor Shakirah Mat Akhir. 2016. Interpretation of Quranic verses regarding environmental care. Afkar 18: 91-130.

Hashim, Nor Hashimah. 2000. Teachers' Understanding of the Application of Moral Values in the Subjects of English in Primary Schools. Research Report of Centre of Educational Studies. Georgetown: Universiti Sains Malaysia.

Hassan, Nurul Hasna, Zaharah Hussin, Saedah Siraj, Ahmad Arifin Sapar, and Zawawi Ismail. 2019. Critical thinking skills in Malay language textbooks standard curriculum of primary school level II. JuKu: Jurnal Kurikulum E Pengajaran Asia Pasifik 7: 18-29. Available online: https:/ / pdfs.semanticscholar.org/aaf3/b7bc7b0acda192a47195adafe96aa9626634.pdf (accessed on 21 October 2019).

Hungerford, Harold R., William. J. Bluhm, Trudi L. Volk, and John. M. Ramsey. 2005. The Tbilisi Declaration. In Essential Readings in Environmental Education, 3rd ed. Champaign: Stripes Publishing.

Hussin, Zaharah, Saedah Siraj, Zai Hazreen Ab Malik, Mohd Ridhuan Mohd Jamil, Ahmad Arifin Sapar, and Nurulrabihah Mat Noh. 2015. Development of behaviour and moral towards sustainable society. Al-Hikmah 7: 72-87.

Ismail, Rozmi. 2017. Theory and Practices in Research Methodology, 4th ed. Bangi: Penerbit Univerisiti Kebangsaan Malaysia.

Juwita, Tita, Nur Ilmiyati, and Adi Maladona. 2017. Feasibility analysis of IPA curriculum 2013 student textbooks on the digestive system material of class viii for use in the learning process in terms of content relevance, accuracy and complexity. Journal Bio Education 2: 63-70.

Kamidin, Tiwi, and Samsilah Roslan. 2014. An Ecopsychological Approach in the Implementation of Environmental Education. Serdang: Universiti Putra Malaysia.

Khalib, Jariah, Mariah Omar, Badariah Hamzah, and Shamsulikram Abdul Hamid. 2017. Science KSSM Form 2. Shah Alam: Penerbit Karangkraf Network Sdn. Bhd.

Liu, Yang, and Myint Swe Khine. 2016. Content Analysis of the Diagrammatic Representations of Primary Science Textbooks. Eurasia Journal of Mathematics, Science \& Technology Education 12: 1937-51.

Love, Eric, and David Pimm. 1996. 'This is so': A text on texts. In International Handbook of Mathematics Education. Dordrecht: Springer, pp. 371-409.

Mangunjaya, Fachruddin Majeri. 2010. Developing environmental awareness and conservation through Islamic teaching. Journal of Islamic Studies 22: 36-49. [CrossRef]

Mănoiu, Valentina-Mariana, Recep Arslan, Azzeddine Madani, and Ertan Düzgüneş. 2016. Environmental education in the holy Quran. Lucrările Seminarului Geografic" Dimitrie Cantemir 42: 157-64.

Marinkovic, Snežana, and Milomir Eric. 2014. The problem of value in a textbook. Procedia—Social and Behavioral Sciences 128: 72-76. [CrossRef] 
Markom, Ruzian, and Norizan Hassan. 2014. Environmental Sustainability and Green Technology Financing from the Perspective of Sharia Law. Available online: https://www.researchgate.net/profile/Norizan_Hassan/publication/305210204_KELESTARIAN_ ALAM_SEKITAR_DAN_PEMBIAYAAN_TEKNOLOGI_HIJAU_DARI_PERSPEKTIF_UNDANGUNDANG_SYARIAH/links/ 5784e28d08ae37d3af6da7e8.pdf (accessed on 30 September 2019).

McKay, Jeanne E., Fachruddin Majeri Mangunjaya, Yoan Dinata, Stuart R. Harrop, and Fazlun Khalid. 2013. Practise what you preach: A faith-based approach to conservation in Indonesia. Fauna and Flora International Oryx 48: 23-29. [CrossRef]

Ministry of Education Malaysia (MOE). 1998. Environmental Education Teacher Handbook across the KBSR and KBSM Curriculum. Kuala Lumpur: Pusat Perkembangan Kurikulum.

Ministry of Education Malaysia (MOE). 2013. Malaysia Education Blueprint 2013-2025. Putrajaya: Kementerian Pendidikan Malaysia.

Ministry of Education Malaysia (MOE). 2019. Implementation of Civic Education by the Ministry of Education Malaysia. Available online: https:/ / www.moe.gov.my/en/soalan-lazim-menu/kurikulum/pelaksanaan-pendidikan-sivikoleh-kementerianpendidikanMalaysia (accessed on 26 December 2019).

Mohamad, Baharom, Ali Suradin, and Za'aba Helmi Khamisan. 2008. The role of Islamic and moral education in building a quality of student personality. Paper presented at Persidangan Pembangunan Pelajar Peringkat Kebangsaan 2008 Universiti Teknologi Malaysia, Skudai, Malaysia, October 22-23, pp. 1-18.

Mohamed, Rosmawati, and Munirah Ghazali. 2019. Elements across the Curriculum in Primary School Mathematics Textbooks: A Malaysian Perspective. European Proceedings of Social and Behavioural Sciences, 387-99. [CrossRef]

O’Riordian, Tim. 1981. Environmentalism. London: Pion Limited.

Othman, Mohd Yusof. 2014. Introduction of Tauhidic Science. Kuala Lumpur: Dewan Bahasa dan Pustaka.

Palmer, Joy. 1998. History and development of Environmental Education. In Environment Education in the 21st Century: Theory, Practice, Progress and Promise. London: New Fatter Lane.

Peters, Robert Francis, and Amnah Abdullah. 2017. Communication and understanding of scientific information in primary Science textbooks: A case study about delivery method. Malaysian Journal of Education 42: 79-86.

Ramsaroop, Sarita, and Hugo Van Rooyen. 2013. Exploring educator competence in teaching environmental education in schools in Gauteng. Africa Education Review 10: 595-613. [CrossRef]

Rusdi, Mikdar. 2010. Preservation and Conservation of the Environment According to the Perspective of the al-Quran. Johor: Penerbit UTHM.

Ruslan, Ruslan. 2018. God, human and nature in the perspective of Islamic philosophy. Qolamuna: Jurnal studi Islam 4: 111-32.

Salleh, Khalijah Mohd. 2011. Science Education Based on Tauhid. Selangor: UKM Publisher.

Schwartz, Shalom H. 2012. An Overview of the Schwartz Theory of Basic Values. Online Readings in Psychology and Culture 2. [CrossRef]

Syahrony, Aisyah, Maimum Aqsha Lubis, and Nik Mohd Rahimi Nik Yusooff. 2017. The importance of textbook readability in the world of education. ASEAN Comparative Education Research Journal on Islam and Civilization (ACER-J) 1: 25-40.

Verma, Gunjan, and Poonam Dhull. 2017. Environmental education as a subject in schools. International Journal of Advanced Research 5: 1547-52. [CrossRef]

Wan Abdullah, Wan Ali Akhbar, Johar Seman, and Salina Basrawi. 2017. Islamic Education KSSM Form 2. Shah Alam: Karangkraft Network Sdn. Bhd. Press.

Weiland, Ingrid S., and Judith A. Morrison. 2013. The integration of environmental education into two elementary preservice Science methods courses: A content-based and a method-based approach. Journal of Science Teacher Education 24: 1023-47. [CrossRef]

Yaacob, Mashitoh, Zubaidah Mohd Nasir, Wan. Syairah Hazwani Wan Petera, Hassan Basri, Ibnor Azli Ibrahim, Mohd Yusof Othman, Mohd Izhar Ariff Mohd Kashim, Azami Zaharim, and Mazlin Mokhtar. 2017. Transformation of Muslim Behaviour towards Sustainable Environment: Perspectives of Non-Governmental Organisations in Klang Valley. Akademika 87: 19-30. [CrossRef]

Yusmium, Ika. 2015. Analysis of Life Sciences Subject Books SMP/MTs Curriculum 2013. Master's thesis, Faculty of Education, Universitas Islam Negeri Walisongo, Semarang, Central Java, Indonesia.

Zandvliet, David. 2001. Towards a Holistic View of Environmental Education. NARST Symposium on Relations between Science Education and Environmental (Science) Education. Available online: http://www.nku.edu/ \{\}Scienceed/NARST_319.PDF (accessed on 5 January 2020). 